Endocrinol. Japon. 1988, 35 (1), 159-164

\title{
NOTE
}

\section{Effect of Serum Magnesium Concentration on Renal Handling of Phosphate in a Patient with Primary Hypomagnesemia}

\author{
Soroku NiSHIYAMA, Hiroshi MITSUBUCHI, Masayuki IKUTA, \\ TAKAO OHTA AND ICHIRO MATSUDA
}
Department of Pediatrics, Kumamoto University Medical School, 111 Honjo, Kumamoto 860, Japan

\begin{abstract}
We examined a case of primary hypomagnesemia with associated hypocalcemia and hyperphosphatemia. It was found, on treatment with magnesium, that there was a significant negative correlation between the serum magnesium level and the percent tubular reabsorption of phosphate, especially when the serum magnesium concentration was above $1.0 \mathrm{mg} / \mathrm{dl}$, in the patient. It is suggested that the serum magnesium concentration might play an important role in urinary phosphate excretion, probably in relation to the parathyroid hormone function.
\end{abstract}

Primary hypomagnesemia is a rare genetically determined disorder of magnesium metabolism in which the defect is thought to be specific intestinal malabsorption of magnesium (Arnold et al., 1983). Affected patients usually experience convulsions in the first three months of life due to accompanying hypocalcemia. Administration of magnesium dramatically corrects the calcium and phosphate levels in such patients. Therefore, the serum magnesium level was thought to play an important role in the parathyroid hormone function. We examined a case of primary hypomagnesemia, and investigated the relationship between the serum magnesium level and the parathyroid hormone function including urinary phosphate excretion.

Received March 17, 1987

\section{Case Report}

A two month-old boy was born after an uncomplicated pregnancy of 40 weeks' gestation. His birth weight was $3,230 \mathrm{~g}$ and length $48.0 \mathrm{~cm}$. He was the second child of healthy and unrelated parents, although his grandfather's father and mother were first cousins, and three of the grandfather's brothers died due to convulsions in childhood.

The patient experienced a generalized convulsion at 2 months of age. His height was $57.0 \mathrm{~cm}$ and weight $5,900 \mathrm{~g}$. Physical examination revealed slight expansion of the large fontanelle and rigidity of the extremities. Neither cataract, shortness of the fourth metacarpal bone nor ectopic subcutaneous calcification were seen in the patient. Laboratory examinations showed low serum calcium, $6.0 \mathrm{mg} / \mathrm{dl}$ (normal range, 
8.5-10.5 mg/dl), and ionized calcium, 0.82 $\mathrm{mmol} / 1$ (normal range, $1.16-1.31 \mathrm{mmol} / \mathrm{l}$ ) levels. Serum phosphate was $8.5 \mathrm{mg} / \mathrm{dl}$ (normal range, $4.2-6.2 \mathrm{mg} / \mathrm{dl}$ ) and serum alkaline phosphatase $367 \mathrm{u} / 1$ (normal range, 210-360 u/1). Immunoreactive C-terminal parathyroid hormone and calcitonin determined with a commercially available kit were $0.24 \mathrm{ng} / \mathrm{ml}$ (normal range, 0.1-0.5 $\mathrm{ng} / \mathrm{ml}$ ) and $130 \mathrm{pg} / \mathrm{ml}$ (normal range, less than $160 \mathrm{pg} / \mathrm{ml}$ ), respectively. Serum 25 hydroxy vitamin $\mathrm{D}$ and $1 \alpha, 25$-dihydroxy vitamin $D_{3}$ were $17 \mathrm{ng} / \mathrm{ml}$ (normal range, 9.2-34.1 $\mathrm{ng} / \mathrm{ml}$ ) and $22 \mathrm{pg} / \mathrm{ml}$ (normal range,
$18.2-92.1 \mathrm{pg} / \mathrm{ml})$, respectively. Immediately after admission, based on the diagnosis of hypoparathyroidism, the patient received $1 \alpha$-hydroxy vitamin $\mathrm{D}_{3}(1.5 \mu \mathrm{g} /$ day $)$ and hydroxy aluminum $(3.0 \mathrm{~g} /$ day $)$. The patient reacted to this therapy, as shown by the fact that his serum calcium and phosphate levels rose to $9.0 \mathrm{mg} / \mathrm{dl}$ and $5.0 \mathrm{mg} / \mathrm{dl}$, respectively, and the clinical features improved (Figure 1). However, the percent tubular reabsorption of phosphate remained high, in the range of 97 to $99 \%$, at this stage. Two weeks after admission, serum magnesium was measured and found to be
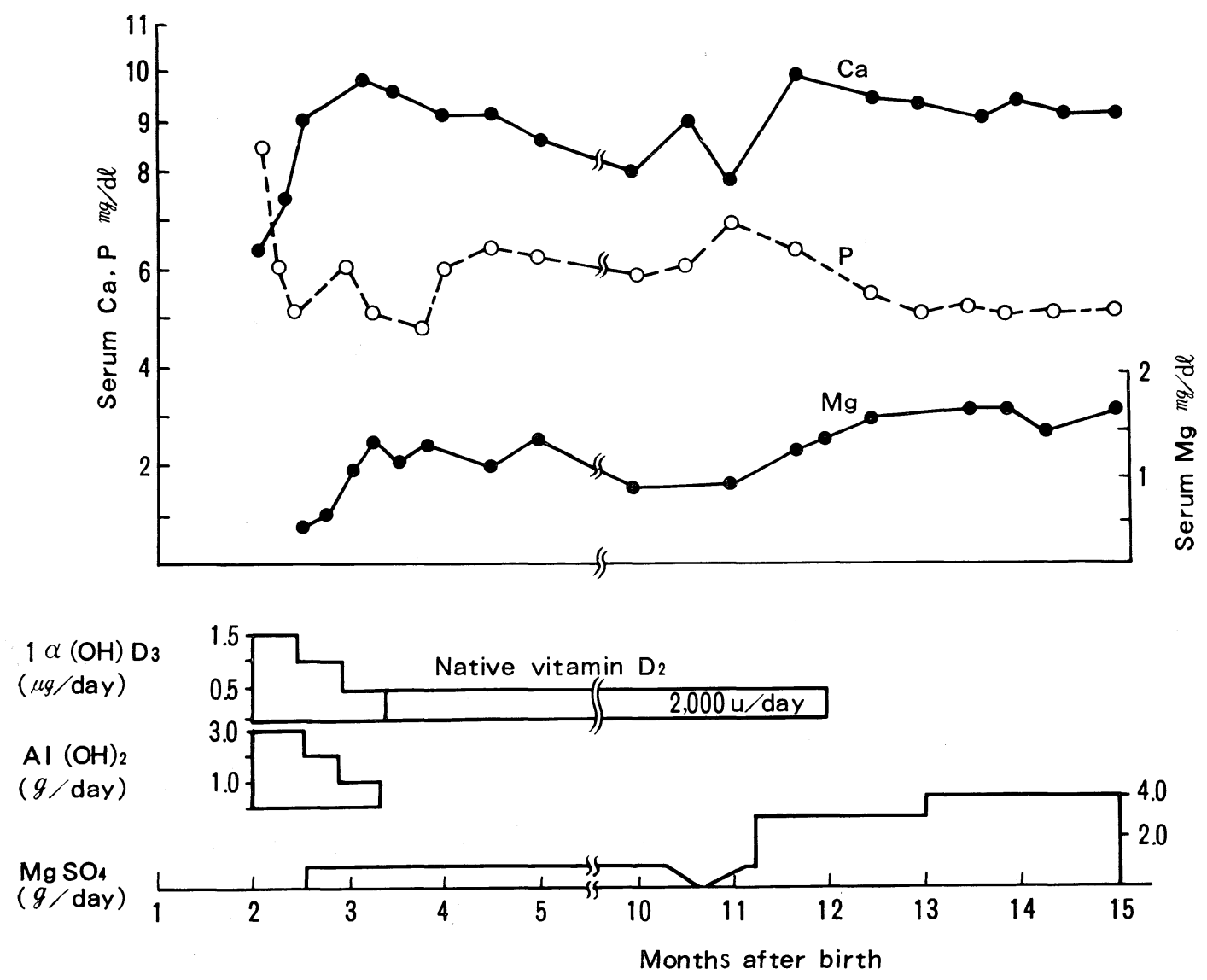

Fig. 1. Clinical course of this case.

$1 \alpha(\mathrm{OH}) \mathbf{D}_{3} ; 1 \alpha$ hydroxy vitamin $\mathbf{D}_{3}$ $\mathrm{AI}(\mathrm{OH})_{2}$; hydroxy alminium 
decreased, being $0.4 \mathrm{mg} / \mathrm{dl}$ (normal, 1.5-2.5 $\mathrm{mg} / \mathrm{dl}$ ). Then oral magnesium supplementation $(2 \mathrm{mEq} / \mathrm{kg})$ was started, together with gradual reduction of the doses of $1 \alpha$-hydroxy vitamin $\mathrm{D}_{3}$ and hydroxy aluminium followed by native vitamin $D_{2}(2,000$ unit/day $)$ by the age of 12 months. The serum magnesium concentration had increased to $1.2-1.4$ $\mathrm{mg} / \mathrm{dl}$ after two weeks administration of magnesium. At the age of 14 months, he received oral magnesium supplementation, $3 \mathrm{mEq} / \mathrm{kg}$ body weight, without native vitamin $\mathrm{D}_{2}$ or hydroxy aluminium, his serum magnesium, calcium and phosphate concentrations being $1.4 \mathrm{mg}, 9.2 \mathrm{mg}$ and 5.2 $\mathrm{mg} / \mathrm{dl}$, respectively (Figure 1). The percent tubular reabsorption of phosphate in the patient was reduced to $75-90 \%$ during the magnesium supplementation. With this therapy, no clinical problem was encountered, and his growth and development were within the normal range.

Magnesium loading test was performed in the patient at the age of 18 months, and in a 15-years-old male patient with idiopathic hypoparathyroidism treated with $1 \alpha$-hydroxy vitamin $\mathrm{D}_{3}$ as a reference (Informed consent was obtained from his family). The solution contained $0.8 \mathrm{mEq} / \mathrm{ml}$ of elemental magne- sium $\left(10 \% \mathrm{MgSO}_{4} \cdot 7 \mathrm{H}_{2} \mathrm{O}\right)$ and was given to each patient $(0.5 \mathrm{ml} / \mathrm{kg}$ of body weight) over two minute into one antecubital vein. Blood samples were collected from an indwelling catheter set in an opposite antecubital fossa vein before and 5, 15, 30 and 60 minutes after the injection. Urine samples were also collected 2 hours and 1 hour before, and 1 and 2 hours after the study. As shown in Table, the concentration of serum C-parathyroid hormone, calcium and magnesium were increased significantly compared to before the injection, and increases in C-parathyroid hormone were accompanied by decreases in the percent tubular reabsorption of phosphate, indicating phosphaturia. On the other hand, in spite of an increase in the serum magnesium concentration, serum C-parathyroid hormone, calcium and the percent tubular reabsorption of phosphate were essentially unchanged before and after the injection in the reference patient with idiopathic hypoparathyroidism.

When the relationships between the concentrations of serum magnesium and immunoreactive parathyroid hormone, and the percent tubular reabsorption of phosphate were taken into account during the above treatment, a significant negative correlation

Table. Results of magnesium loading test

\begin{tabular}{|c|c|c|c|c|c|c|c|c|c|c|}
\hline \multirow{2}{*}{$\begin{array}{l}\text { Time minute } \\
\text { Serum } \\
\end{array}$} & \multicolumn{5}{|c|}{ Patient with hypomagnesemia } & \multicolumn{5}{|c|}{ Patient with IHP } \\
\hline & before & 5 & 15 & 30 & 60 & before & 5 & 15 & 30 & 60 \\
\hline C-PTH ng/ml & 0.28 & 0.25 & 0.52 & 0.33 & 0.34 & 0.12 & 0.12 & 0.13 & 0.12 & ND \\
\hline Calcium $\mathrm{mg} / \mathrm{dl}$ & 9.2 & 9.3 & 10.5 & 10.4 & 9.6 & 9.4 & 9.5 & 9.4 & 9.5 & 9.3 \\
\hline Magnesium mg/dl & 1.5 & 2.2 & 2.9 & 2.6 & 2.8 & 1.7 & 2.3 & 3.2 & 3.1 & 2.9 \\
\hline $\begin{array}{l}\text { Time hour } \\
\text { Urine }\end{array}$ & -2 & & & 1 & 2 & -2 & & & 1 & 2 \\
\hline$\%$ TRP & 82.7 & 83 & & 67.2 & 79.8 & 95.5 & $95 . \varepsilon$ & & 94.7 & 97.8 \\
\hline
\end{tabular}

IHP : Idiopathic hypoparathyroidism ND: Not detected

C-PTH : Immunoreactive carboxy-terminal parathyroid hormone

\% TRP: The percent tubular reabsorption of phosphate 

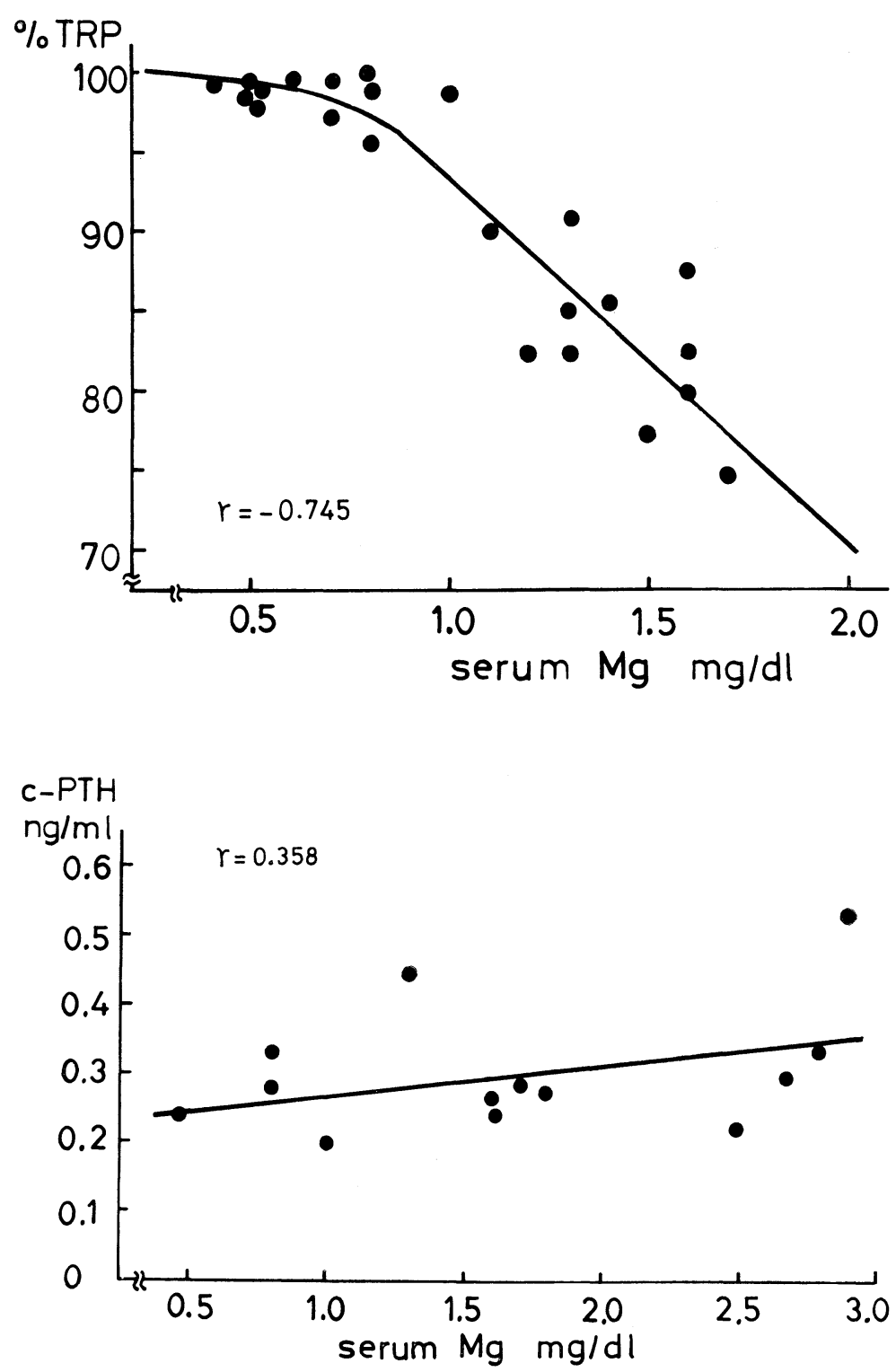

Fig. 2. Relationship between serum magnesium concentration and the percent tubular reabsorption of phosphate during magnesium supplementation. When the serum magnesium concentration was above $\mathbf{1 . 0}$ $\mathrm{mg} / \mathrm{dl}$, linear regression analysis was performed with the following equation:

$$
\begin{aligned}
& y=-21.7 x+114.8, \\
& n=12, \gamma=-0.745, \\
& \mathrm{p}<0.01 .
\end{aligned}
$$

Fig. 3. Relationship between serum magnesium concentration and C-terminal PTH during magnesium supplementation.

$y=0.039 x+0.237$, $n=13, \gamma=0.358$, $\mathrm{p}>0.05$. was found between the serum magnesium concentration and the percent tubular reabsorption of phosphate (the $\gamma$ and $p$ values are shown in Figure 2), but not between the serum magnesium and immunoreactive parathyroid hormone levels (the $\gamma$ and $\mathrm{p}$ values are shown in Figure 3).

\section{Discussion}

It is well known that hypomagnesemia is accompanied by hypocalcemia and hyperphosphatemia in man. Several explanations for this have been offered, e.g. hypomagnesemia might disturb the secretion of 
parathyroid hormone (Anast et al., 1976; Suh et al., 1973), and the unresponsiveness of target organs to the administration of parathyroid hormone is likely during hypomagnesemia (Estep et al., 1969; Freitag et al., 1979; Medalle et al., 1973).

Recently, Graber et al. (1986) reported a case in which hypocalcemia may simply represent a direct effect of magnesium depletion on bone independent of the effects of parathyroid hormone. Furthermore, Rude et al. (1985) proposed that magnesium depletion may impair vitamin $\mathrm{D}$ metabolism. A detailed study was performed by Allgrove et al., who examined the relationship between the serum magnesium concentration and parathyroid hormone function in patients with secondary hypomagnesemia, by measuring carboxy-terminal parathyroid hormone, amino-terminal parathyroid hormone and biologically active parathyroid hormone (Allgroves et al., 1984). They proposed the possibility that increased magnesium in the serum might play an important role in the secretion of biologically active parathyroid hormone in patients with the disease. Although only one patient with primary hypomagnesemia was studied, on many occasions throughout the clinical course, we observed the significant negative correlation found between serum magnesium and percent tubular reabsorption of phosphate. This observation supports the results of Allgrove's study clinically, when it is assumed that renal handling of phosphate reflects a biologically active parathyroid function, and the C-terminal parathyroid hormone levels in the present study poorly reflect the real activity of the parathyroid.

Further supportive data were obtained by a magnesium loading test performed in the patient and in a reference patient with idiopathic hypoparathyroidism. It was clearly demonstrated that the percent tubular reabsorption of phosphate was suppressed only when increased serum magnesium concentrations were accompanied with an increase in serum parathyroid hormone; otherwise the percent tubular reabsorption of phosphate was not changed even when serum magnesium was increased. Nair et al. indicated that even with severe magnesium deficiency, phosphaturic response was normal so long as serum parathyroid hormone concentrations were normal (Nair et al., 1979). Therefore, it is unlikely that the amount of serum magnesium might directly affect tubular phosphate excretion. Similarly, with regard to the correlation between serum magnesium and calcium concentrations, magnesium loading studies in these patients may indicate that an increase in serum calcium could be induced by an increase in parathyroid hormone but not by an increase in magnesium itself.

In the present study, urinary phosphate excretion was increased characteristically, when the serum magnesium concentration was more than $1.0 \mathrm{mg} / \mathrm{dl}$. Allgrove et al. reported that the serum calcium concentration became normal when the serum magnesium concentration was more than $1.2 \mathrm{mg} / \mathrm{dl}$ (Allgroves et al., 1984). This suggested that the parathyroid hormone function might become normal when the magnesium concentration is $1.0-1.2 \mathrm{mg} / \mathrm{dl}$ in a patient with hypomagnesemia.

\section{References}

Allgrove, J., S. Adami, L. Fraher, A. Reuben and J. L. H. O'Riordan (1984). Hypomagnesemia: Studies of parathyroid hormone secretion and function. Clin. Endocrinol. 21, 435449.

Anast, C. S., J. L. Winnacker, L. R. Forte and T. W. Burns (1976). Impaired release of parathyroid hormone in magnesium deficiency. J. Clin Endocrinol. Metab. 42, 701-717.

Arnold, J. D., R. K. Oldfield, A. C. Pollard and M. Silink (1983). Primary hypomagnesemia: case report. Aust Paediatr. J. 19, 4546.

Estep, H., W. A. Shaw, C. Watlington, R. Hobe, 
W. Holland and S. T. G. Tucker (1969). Hypocalcemia to hypomagnesemia and reversible parathyroid hormone unresponsiveness. J. Clin. Endocrinol. 29, 842-848.

Freitag, J. J., K. J. Martin and M. B. Conrades (1979). Evidence for skeletal resistance to parathyroid hormone in magnesium deficiency. J. Clin. Invest . 64, 1238-1244.

Graber, M. S. and G. Schulman (1986). Hypomagnesemic hypocalcemia independent of parathyroid hormone. Ann. Intern. Med. 104, 804-805.

Medalle, R. and C. Waterhouse (1973). A magnesium deficiency patient presenting with hypocalcemia and hyperphosphatemia. Ann. Intern. Med. 79, 76-79.
Nair, K. S., I. M. Holdaway, M. S. Evans and A. D. Cameron (1979). Influence of magnesium on the secretion and action of parathyroid hormone. J. Endocrinol. Invest. 2, 267-270.

Rude, R. D., J. S. Adams, E. Ryzen, D. B. Endres, H. Niimi, R. L. Horst, J. G. Haddad and R. R. Singer (1985). Low serum concentration of 1,25-dihydroxy vitamin $\mathrm{D}$ in human magnesium deficiency. J. Clin. Endocrinol. Metab. 61, 933-940.

Suh, S. M., A. H. Tashijian, N. Matsuo, D. K. Parkinson and D. Fraser (1973). Pathogenesis of hypocalcemia in primary hypomagnesemia : normal end-orgen responsiveness to parathyroid hormone, impaired parathyroid gland function. J. Clin. Invest. 52, 153-160. 